\title{
Comparative Genotoxicity of Cadmium and Lead in Earthworm Coelomocytes
}

\author{
Ptumporn Muangphra ${ }^{1}$ and Ravi Gooneratne ${ }^{2}$ \\ ${ }^{1}$ Biology Department, Faculty of Science, Silpakorn University, Nakorn Pathom 73000, Thailand \\ ${ }^{2}$ Faculty of Agriculture and Life Science, Lincoln University, Canterbury, Lincoln 7647, New Zealand
}

Correspondence should be addressed to Ravi Gooneratne, ravi.gooneratne@lincoln.ac.nz

Received 1 December 2010; Accepted 11 March 2011

Academic Editor: Marco Trevisan

Copyright (C) 2011 P. Muangphra and R. Gooneratne. This is an open access article distributed under the Creative Commons Attribution License, which permits unrestricted use, distribution, and reproduction in any medium, provided the original work is properly cited.

\begin{abstract}
To determine genotoxicity to coelomocytes, Pheretima peguana earthworms were exposed in filter paper studies to cadmium $(\mathrm{Cd})$ and lead $(\mathrm{Pb})$ for $48 \mathrm{~h}$, at concentrations less than the $\mathrm{LC}_{10}-\mathrm{Cd}: 0.09,0.19,0.38,0.75$, and $1.50 \mu \mathrm{g} \mathrm{cm}^{-2} ; \mathrm{Pb}: 1.65,3.29$, $6.58,13.16$, and $26.32 \mu \mathrm{g} \mathrm{cm}{ }^{-2}$. For Cd at $0.75 \mu \mathrm{g} \mathrm{cm}^{-2}$, in the micronucleus test (detects chromosomal aberrations), significant increases $(P<.05)$ in micronuclei and binucleate cells were observed, and in the comet assay (detects DNA single-strand breaks), tail DNA\% was significantly increased. Lead was less toxic with minimal effects on DNA, but the binucleates were significantly increased by $\mathrm{Pb}$ at $3.29 \mu \mathrm{g} \mathrm{cm}^{-2}$. This study shows that $\mathrm{Cd}$ is more acutely toxic and sublethally genotoxic than $\mathrm{Pb}$ to $P$. peguana. Cadmium caused chromosomal aberrations and DNA single-strand breaks at $45 \%$ of the $\mathrm{LC}_{10}$ concentration. Lead, in contrast, did not induce DNA damage but caused cytokinesis defects.
\end{abstract}

\section{Introduction}

Earthworms are primary decomposers of soil organic matter and, thus, aid in improving soil quality and fertility. Earthworms are a dominant component of the soil faunal biomass, providing $10-200 \mathrm{~g} \mathrm{~m}^{-2}$ [1]. Because of their ecological importance, earthworms are now adopted as an indicator organism for the assessment of potential impact of chemicals to soil organisms.

In agricultural operations worldwide, there is increasing concern about widespread soil contamination by chemicals and heavy metals. Cadmium $(\mathrm{Cd})$ and lead $(\mathrm{Pb})$ are two of the more toxic heavy metals released into soil by industrial processes. They are of particular concern because they have no biological function but are toxic to living organisms and pose a risk to human and environmental health. In polluted soil, earthworms are exposed to these pollutants both dermally and through gastrointestinal tract absorption from soil. The earthworm immune system is generally sensitive to heavy metal exposure. Exposure of earthworms to chemicals via the dermal route affects coelomocytes directly and, therefore, have a major influence on the health of earthworms.
Therefore, monitoring earthworm immune competence can be regarded as a more sensitive and early-warning biomarker of ecosystem health.

Inorganic $\mathrm{Pb}$ is classified as a group IIA carcinogen, which is a probable human carcinogen [2]. Cd is classified as a group I human carcinogen [3] and an animal carcinogen [4]. In addition, Cd interferes with DNA repair, which can lead to mutations [5] and eventually carcinogenesis [6]. Therefore, assessment of DNA damage is an important aspect of toxicity testing. Earthworm coelomocytes play a significant role in earthworm immunity [7] and, therefore, are frequently used to assess genotoxicity.

The comet assay has been used as a sensitive tool to measure DNA damage in a variety of organisms [8-10], while the micronucleus test, a cytogenetic technique, has been used to detect chromosomal aberrations and nuclear abnormalities such as binuclei and micronuclei-these are well-established indicators of cytotoxicity and genetic toxicology, respectively $[11,12]$.

In order to better understand $\mathrm{Cd}$ and $\mathrm{Pb}$ toxicity on the earthworm Pheretima peguana, this study aimed to determine the minimum $\mathrm{Cd}$ and $\mathrm{Pb}$ concentrations that 
would cause genotoxicity via dermal route of exposure, by measuring immune competence as reflected by chromosomal aberrations and DNA damage to coelomocytes. The frequencies of coelomocyte micronuclei and binucleate cells were used to assess chromosomal aberrations and inhibition of cytokinesis, respectively. Tail DNA\% and DNA tail length were measured by the comet assay to assess DNA singlestrand breaks. The study sought to confirm that the comet assay and micronucleus test are tools that can be used in genotoxicity assessment of $\mathrm{Cd}$ and $\mathrm{Pb}$ for ecotoxicity risk comparison.

\section{Materials and Methods}

2.1. Earthworms. Pheretima peguana earthworms were sourced from a local dealer in Bangkok, Thailand. The worms were maintained in the laboratory using a stock soil (50\% loamy topsoil, 30\% composted leaves and 20\% animal manure) at $28 \pm 1{ }^{\circ} \mathrm{C}, 65 \%$ humidity, with a 12 -h light: 12 -h dark photoperiod. Watermelons were added once a week to supplement the stock soil. Adult individuals (300-600 mg) with a well-developed clitellum were used in all experiments. Prior to the experiment, the worms were removed from the stock soil, rinsed with water, blotted on filter paper, and kept in the dark at $28 \pm 1^{\circ} \mathrm{C}$ for 24 -h to allow depuration of gut contents.

2.2. Chemicals. Cadmium chloride $\left(\mathrm{CdCl}_{2}\right)$ and lead nitrate $\left[\mathrm{Pb}\left(\mathrm{NO}_{3}\right)_{2}\right]$ (Sigma Aldrich Chemical Co.) were diluted in double-distilled water to achieve the desired concentrations. All reagents were of analytical grade and prepared in Milli-Q grade water. Whatman no. 1 filter paper was placed in flat glass containers $(2 \times 9 \mathrm{~cm})$ and wetted with $3 \mathrm{~mL}$ each of either $\mathrm{Cd}$ or $\mathrm{Pb}$ solutions or distilled water (control).

2.3. Acute Toxicity Studies. The acute toxicity of $\mathrm{Cd}$ and $\mathrm{Pb}$ to earthworms was assessed in a filter paper contact test using five concentrations of each metal $(n=20$ earthworms per concentration) selected based on preliminary studies. The final heavy metal concentrations per square centimeter of filter paper used in the experiment were Cd: 4.70, 5.85, 7.05, 8.23, 9.40, and $10.58 \mu \mathrm{g} \mathrm{cm}^{-2}$ and $\mathrm{Pb}: 32.90,37.60$, $42.30,47.00,51.70$, and $56.40 \mu \mathrm{g} \mathrm{cm}^{-2}$. All experiments were carried out in the dark at $28 \pm 1^{\circ} \mathrm{C}$ for 48 -h. The percentage mortality was determined at $24-\mathrm{h}$ and 48 -h; worms were considered dead when they did not respond to touch of the anterior region. Results of the treatment groups were compared with the controls and analyzed using Probit analysis to calculate the $48-\mathrm{h} \mathrm{LC}_{10}$ and $\mathrm{LC}_{50}$ for $\mathrm{Cd}$ and $\mathrm{Pb}$.

2.4. Sublethal Toxicity Studies. In a sublethal toxicity study, earthworms ( $n=5$ per concentration) were exposed for 48-h to $\mathrm{Cd}$ and $\mathrm{Pb}$ concentrations less than the 48-h $\mathrm{LC}_{10}$-Cd: $0.09,0.19,0.38,0.75,1.50 \mu \mathrm{g} \mathrm{cm}^{-2} ; \mathrm{Pb}: 1.65$, $3.29,6.58,13.16,26.32 \mu \mathrm{g} \mathrm{cm}^{-2}$ filter paper. Distilled water was used as the control. After 48-h, worms from each concentration were removed from the filter paper, washed in distilled water, and blotted on a paper towel. The number of surviving earthworms and their body weights were recorded. Three worms exposed to each metal concentration were used to collect the coelomocytes as described below.

2.5. Harvesting Coelomocytes. Coelomic fluid containing coelomocytes was obtained from the coelomic cavity by the extrusion method of Eyambe et al. [13]. Briefly, the earthworms were rinsed in $3 \mathrm{~mL}$ of saline extrusion medium containing $5 \%$ ethanol, $71.2 \mathrm{mM} \mathrm{NaCl}, 5 \mathrm{mM}$ EGTA, $50.4 \mathrm{mM}$ guaiacol glyceryl ether in a Petri dish, with $\mathrm{pH}$ adjusted to 7.3 with 1.0 M NaOH. Extruded cells were transferred to ice-cold $\mathrm{Ca}^{2+}$ free Lumbricus balanced salt solution (LBSS) containing $71.5 \mathrm{mM} \mathrm{NaCl}, 4.8 \mathrm{mM} \mathrm{KCl}, 1.1 \mathrm{mM} \mathrm{MgSO}{ }_{4} \cdot 7 \mathrm{H}_{2} \mathrm{O}, 0.4 \mathrm{mM}$ $\mathrm{KH}_{2} \mathrm{PO}_{4}, 0.3 \mathrm{mM} \mathrm{Na}_{2} \mathrm{HPO}_{4}$, and $4.2 \mathrm{mM} \mathrm{NaHCO}_{3}$ and $\mathrm{pH}$ adjusted to 7.3 with $1.0 \mathrm{M} \mathrm{NaOH}$ [14].

2.6. Coelomocyte Morphology and Cell Viability. Coelomocyte morphology was examined microscopically. Cells were counted in a haemocytometer and the cell concentration adjusted to $10^{5}$ cells $\mathrm{mL}^{-1}$. Cell viability was determined using the trypan blue exclusion test, after mixing equal volumes of the coelomocyte suspension and a $0.5 \%(\mathrm{w} / \mathrm{v})$ trypan blue (Sigma) solution. Cell viability always exceeded 95\%.

2.7. Micronucleus Test. An aliquot of $10 \mu \mathrm{L}$ of coelomic fluid from each earthworm at each metal concentration was smeared on a glass slide, using three slides for each concentration. When the fluid dried, the coelomocytes were fixed with a methanolic fixative solution for differential staining of cellular components (Wright Rapid Stain). A total of 3,000 small coelomocytes from three separate slides $(1,000$ cells per slide) per concentration were scored using a compound microscope (Olympus, $\mathrm{CH} 30$ ) at 1,000x magnification to determine the micronuclei and binucleate frequencies. The remaining coelomic fluid was used for the comet assay.

2.8. Comet Assay. To detect coelomocyte DNA damage, alkaline lysis followed by alkaline single-cell gel electrophoresis was conducted. Three microgel slides were prepared for each metal concentration according to the protocol of Singh et al. [8] and modifications of S. A. Reinecke and A. J. Reinecke [10]. All steps were conducted in $\operatorname{dim}$ light at $4^{\circ} \mathrm{C}$ to prevent additional DNA damage. An aliquot of $20-\mu \mathrm{L}$ cell suspension was mixed with $75 \mu \mathrm{L}$ of $0.5 \%$ (w/v in PBS, pH 7.3) low-melting agarose (LMA) at $40^{\circ} \mathrm{C}$, and overlaid on a microscopic slide precoated with $100 \mu \mathrm{L}$ of normal melting agarose and immediately closed with a cover glass. Agarose was allowed to solidify by keeping slides on ice packs for $1 \mathrm{~min}$. Cover glasses were removed, and $0.5 \%$ low-melting agarose (prepared in $40 \mathrm{mM}$ Tris- $\mathrm{HCl}, \mathrm{pH} 10.0$ ) was layered on the slide and covered with a cover glass. Slides were then transferred onto ice packs for $1 \mathrm{~min}$. Cover glasses were removed and slides kept in high-salt lysis buffer $(2.5 \mathrm{M} \mathrm{NaCl}$, $100 \mathrm{mM}$ EDTA, $10 \mathrm{mM}$ Tris base, $1 \%$ Triton-X, pH 10.0) for the duration of $15 \pm 1$-h in the dark at $4^{\circ} \mathrm{C}$ to remove cellular proteins and liberate the damaged DNA. Lysis slides were then kept in a horizontal electrophoresis tank 
containing alkaline electrophoresis buffer $(300 \mathrm{mM} \mathrm{NaOH}$, $1 \mathrm{mM}$ EDTA, $\mathrm{pH}>13$ ) for $20 \mathrm{~min}$ to allow unwinding of DNA and to express DNA single-strand breaks and alkali labile sites. Next, electrophoresis was carried out for $30 \mathrm{~min}$ at $12 \mathrm{~V}$ and $300 \mathrm{~mA}$ at $4^{\circ} \mathrm{C}$. Slides were then neutralized with a $0.4 \mathrm{M}$ Tris buffer ( $\mathrm{pH}$ 7.5) thrice at 5 min intervals.

Slides were stained with $100 \mu \mathrm{L}$ of $20 \mu \mathrm{g} \mathrm{mL}^{-1}$ ethidium bromide for $5 \mathrm{~min}$ and washed with deionized water to remove excess stain. The slides were examined under a Nikon eclipse 80i fluorescent microscope with filter block UV-2A (excitation filter $510-560 \mathrm{~nm}$, dichroic mirror $575 \mathrm{~nm}$, emission $590 \mathrm{~nm})$. Images of comets were recorded using a digital camera (Nikon DXM 1200C) and analyzed with the software program LUCIA (Laboratory Universal Computer Image Analyzer). At least 100 nonoverlapping comets per slide were captured randomly at 400x magnification and scored for the comet parameters, namely, tail DNA (TD) \% (expressed as the percent of fluorescent intensity in tail) and DNA tail length (TL) (the distance from nuclear center to the end of the comet tail).

2.9. Statistical Analysis. In the sublethal study, results are expressed as the mean and standard error of the mean from three earthworms. Significant differences between the results of the different treatment groups were determined using oneway ANOVA and Tukey's multiple comparisons. When the normality failed, the Kruskal Wallis $\mathrm{H}$ test was performed.

\section{Results}

3.1. Acute Toxicity Test. Total 48-h earthworm mortality in the control replicates was $<10 \%$, which complies with the validity criteria of the OECD test protocol. Significant toxic effects and deaths were observed with all tested heavy metal concentrations and were most marked at the highest tested concentrations: $10.58 \mu \mathrm{g} \mathrm{cm}^{-2}$ for $\mathrm{Cd}$ and $56.40 \mu \mathrm{g} \mathrm{cm}^{-2}$ for $\mathrm{Pb}$ (Figure 1). The 48-h $\mathrm{LC}_{10}$ and $\mathrm{LC}_{50}$ values for $\mathrm{Cd}$ were 1.65 and $6.09 \mu \mathrm{g} \mathrm{cm}^{-2}$, respectively (Figure $1(\mathrm{a})$ ) and for $\mathrm{Pb}$ 26.64 and $43.43 \mu \mathrm{g} \mathrm{cm}^{-2}$ (Figure 1(b)). Thus, Cd was acutely more toxic than $\mathrm{Pb}$ to $P$. peguana.

3.2. Micronucleus Test. The frequency of binucleate cells at each concentration was higher than for micronuclei, compared with the controls. The frequencies of binucleates and micronuclei in coelomocytes were significantly higher at $\mathrm{Cd}$ concentrations of $0.75 \mu \mathrm{g} \mathrm{cm}^{-2}$ and above compared with the controls (Figure 2(a)). Thus, Cd caused cytokinesis failure and chromosomal aberrations in the form of binucleates and micronuclei, respectively, at a level slightly less than $50 \%$ of the $48-\mathrm{LC}_{10}$.

There was also a significant increase in binucleate coelomocytes at and above $\mathrm{Pb}$ concentrations of $3.29 \mu \mathrm{g} \mathrm{cm}^{-2}$, which is about $12.5 \%$ of the $\mathrm{Pb} 48-\mathrm{h} \mathrm{LC}_{10}$ for earthworms. In contrast to $\mathrm{Cd}, \mathrm{Pb}$ had no significant effect on micronuclei formation even at a concentration close to the $\mathrm{LC}_{10}$ (Figure 2(b)).

At $\mathrm{LC}_{10}$, the frequencies of $\mathrm{Cd}$ - and $\mathrm{Pb}$-induced binucleates were similar: $9.67(\mathrm{Cd})$ and $10.67(\mathrm{~Pb})$ cells per

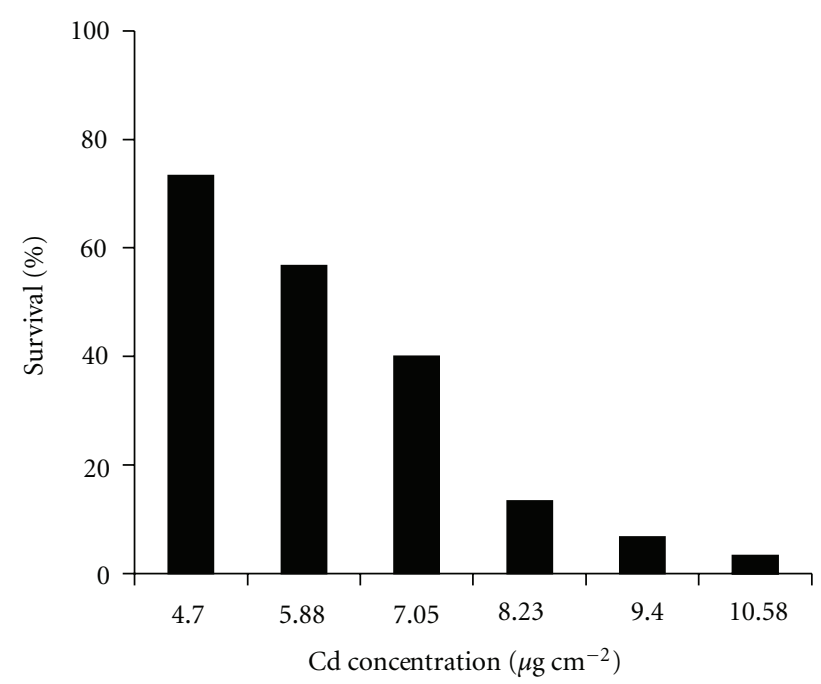

(a)

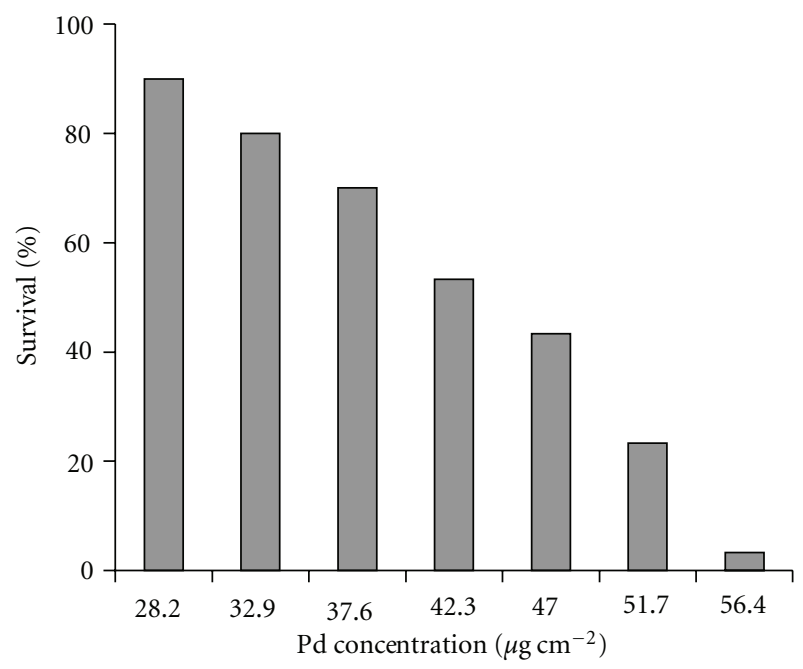

(b)

Figure 1: Percentage survival of Pheretima peguana exposed to (a) $\mathrm{Cd}$ and (b) $\mathrm{Pb}$ in filter paper for 48-h.

1,000 coelomocytes. However, at $\mathrm{LC}_{10}$, the Cd-induced micronuclei frequency of 4.67 per 1,000 coelomocytes was almost three times higher than that observed with $\mathrm{Pb}(1.67)$.

3.3. Comet Assay. The mean coelomocyte tail DNA\% and to a lesser extent DNA tail length increased progressively with increasing Cd concentration (Figures 3(a) and 3(b)). Cadmium at $0.75 \mu \mathrm{g} \mathrm{cm}^{-2}$ filter paper concentration and above, tail DNA\% of coelomocytes increased significantly $(P<.05)$ compared with the controls (Figure 3(a)). At the highest $\mathrm{Cd}$ concentration $\left(1.50 \mu \mathrm{g} \mathrm{cm}^{-2}\right.$, slightly below the $\mathrm{LC}_{10}$ concentration), there was a significant increase $(P<.05)$ in DNA tail length compared with the controls (Figure 3(b)).

There was no significant difference in tail DNA\% (Figure 3(b)) and DNA tail length (Figure 3(d)) between any $\mathrm{Pb}$ treatment groups and the controls. 


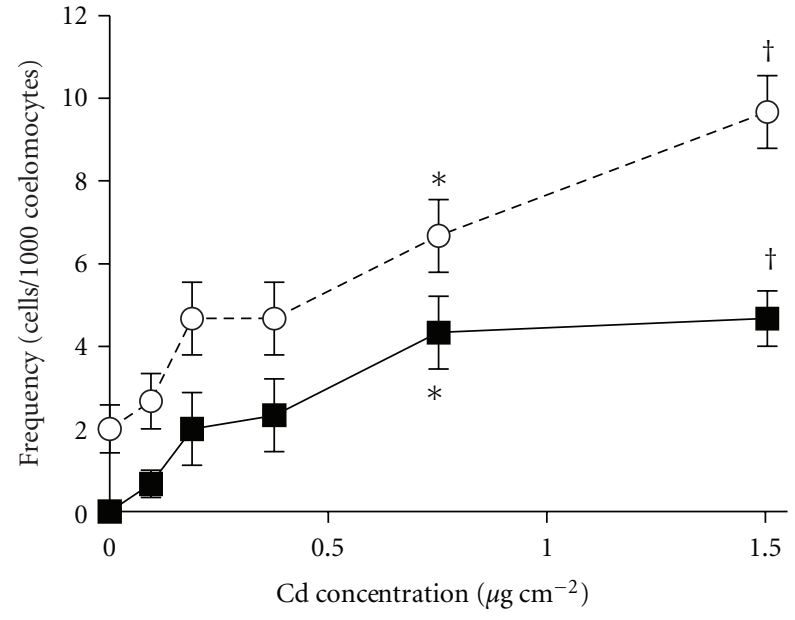

(a)

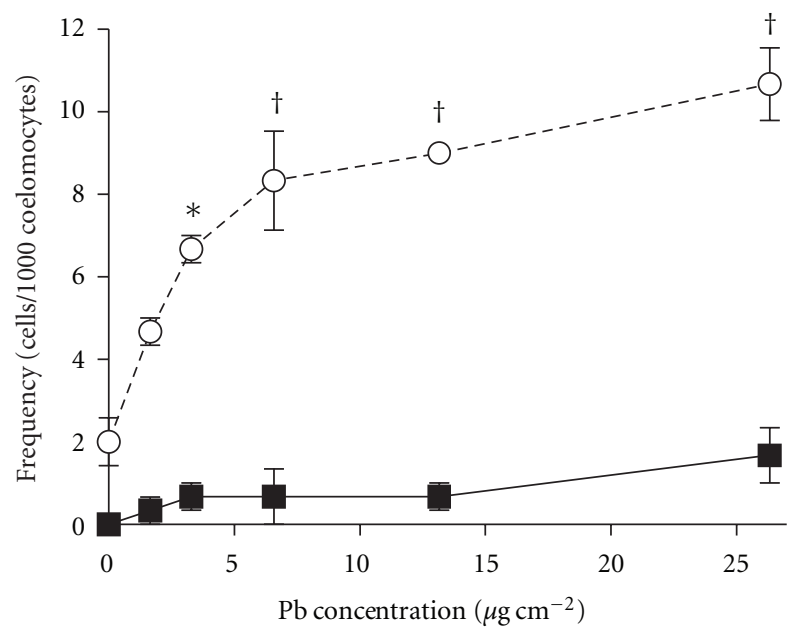

(b)

Figure 2: Micronuclei (black square) and binucleate cell (white circle) frequency (mean $\pm \mathrm{SE}$ ) of Pheretima peguana coelomocytes exposed to (a) Cd and (b) $\mathrm{Pb}$ after 48-h. Significantly different from the control $\left(* P<.05 ;{ }^{\dagger} P<.01\right)$.

\section{Discussion}

The $\mathrm{LC}_{10}$ and $\mathrm{LC}_{50}$ values of $\mathrm{Cd}$ for earthworms were 15 -fold and 7-fold lower, respectively, than those of $\mathrm{Pb}$, indicating that $\mathrm{Cd}$ was more acutely toxic to $P$. peguana than $\mathrm{Pb}$. The exposure time of $48-\mathrm{h}$ to $\mathrm{Cd}$ used in the present study was adequate to induce coelomocyte DNA damage. This is in good agreement with Fourie et al. [15] who used the same exposure time and found tissue Cd accumulation and subsequent DNA damage in earthworms exposed to a slightly higher $\mathrm{Cd}$ concentration in artificial soil-water medium. However, Homa et al. [16] reported that at least 3 days is required for $\mathrm{Cd}$ to accumulate in significant concentration in coelomocytes for induction of stress response proteins in Eisenia fetida exposed to $1.32 \mu \mathrm{g} \mathrm{cm}^{-2} \mathrm{Cd}$ (and $\mathrm{Zn}, \mathrm{Cu}, \mathrm{Pb}$ ) in filter-paper contact tests.

Greater toxicity of $\mathrm{Cd}$ compared with $\mathrm{Pb}$ may be due to the differences in bioavailability and/or absorption and/or compartmentalization of the two metals in the earthworms. This is supported by the studies of Nahmani et al. [17] and $\mathrm{Ma}$ [18]. Li et al. [19] have shown that in Eisenia fetida, about $80 \%$ of cellular Cd was in the cytosol and only $20 \%$ in the cell membrane. This is in contrast to $\mathrm{Pb}$ where $50 \%$ of $\mathrm{Pb}$ was located in the cell membrane and much less in the cytosol. This may be due to the fact that $\mathrm{Pb}^{2+}$ has a larger ionic radius $(1.19 \AA)$ compared with $\mathrm{Cd}^{2+}(0.97 \AA)$, and therefore a greater diffusion of $\mathrm{Cd}$ ions into the coelomocytes, whereas most of the $\mathrm{Pb}^{2+}$ binds to the cell membrane with limited transport to the coelomocyte cytosol and hence minimal toxicity to the coelomocytes.

In the sublethal 48-h study, both $\mathrm{Cd}$ and $\mathrm{Pb}$ increased the binucleate coelomocytes. Binucleate cells occur due to a defect in cytokinesis, the process by which two daughter cells normally separate following cell division. Our results demonstrate that the $\mathrm{Cd}$ concentration $\left(0.75 \mu \mathrm{g} \mathrm{cm}^{-2}\right)$ required to induce binucleate coelomocytes was approximately $25 \%$ of that required for $\mathrm{Pb}\left(3.29 \mu \mathrm{g} \mathrm{cm}^{-2}\right)$. This finding agrees well with the study of Conder and Lanno [20] who reported that $\mathrm{Pb}$ is only slightly toxic and relatively well tolerated by the coelomocytes, compared with $\mathrm{Cd}$, due to sequestration of $\mathrm{Pb}$ by chlorogogue cells. Fugère et al. [7] reported that $\mathrm{Pb}$ was relatively well tolerated by the earthworm coelomocytes whereas $\mathrm{Cd}$ was relatively toxic with effects on both coelomocyte viability and phagocytosis. Moreover, Homa et al. [16] reported that coelomocytes are selectively sensitive to certain metal ions due to differential upregulation of metallothionein by these ions on exposure to a $1.32 \mu \mathrm{g} \mathrm{cm}^{-2}$ concentration of each metal.

Lead treatment did not affect micronuclei frequency even at the highest $\mathrm{Pb}$ exposure concentration of $26.32 \mu \mathrm{g} \mathrm{cm}^{-2}$ in the 48-h sublethal study. Since micronuclei occur as a short-term response to a genotoxic substance [21], their expression frequency depends more on the exposure dose than the exposure duration [12]. The significant increase in binucleate coelomocytes when $\mathrm{Pb}$ concentration was at and above $3.29 \mu \mathrm{g} \mathrm{cm}^{-2}$ implies that $3.29 \mu \mathrm{g} \mathrm{cm}^{-2}$ (equivalent to approximately $12.5 \%$ of the $48-\mathrm{h} \mathrm{LC}_{10}$ value) can be regarded as a sublethal $\mathrm{Pb}$ dose. $\mathrm{Pb}$ appears to have a greater effect on cytokinesis than on chromosomes in earthworm coelomocytes.

A significant increase in micronuclei in earthworm coelomocytes, an indication of chromosomal aberrations during mitosis on exposure to $\mathrm{Cd}$ at $0.75 \mu \mathrm{g} \mathrm{cm}^{-2}$, equivalent to approximately $50 \%$ of the calculated $48-\mathrm{h} \mathrm{LC}_{10}$, can be regarded as a sublethal effect because in this experiment no earthworm deaths occurred at this concentration. The Cdinduced formation of micronuclei and binucleate cells in earthworm coelomocytes is in agreement with cytotoxic and genotoxic effects of Cd on mammals [22, 23]. Genotoxicity to earthworm coelomocytes at $48-\mathrm{h} \mathrm{LC}_{10}$ can be extrapolated as that exposure of earthworms even to a slightly Cd contaminated soil may result in genetic material damage in chromosomes and DNA, with consequences to earthworms and, hence, to the terrestrial ecosystem in general. On exposure to higher Cd concentrations, tail DNA\% indicative of singlestrand breaks progressively increased and was significantly 


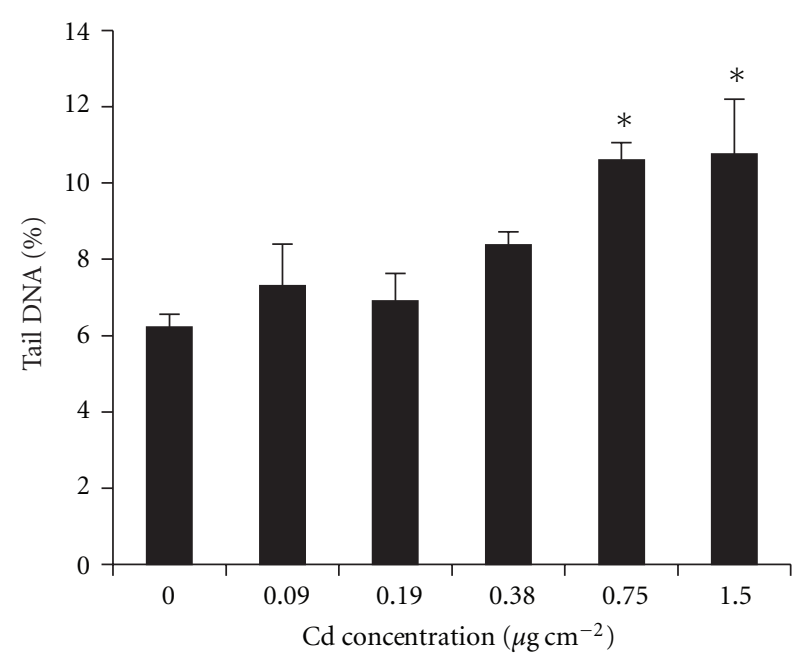

(a)

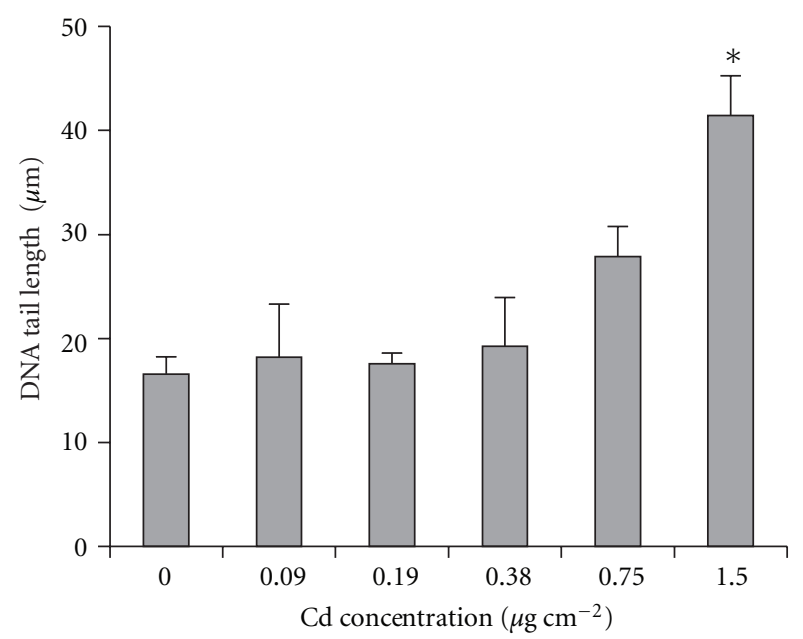

(c)

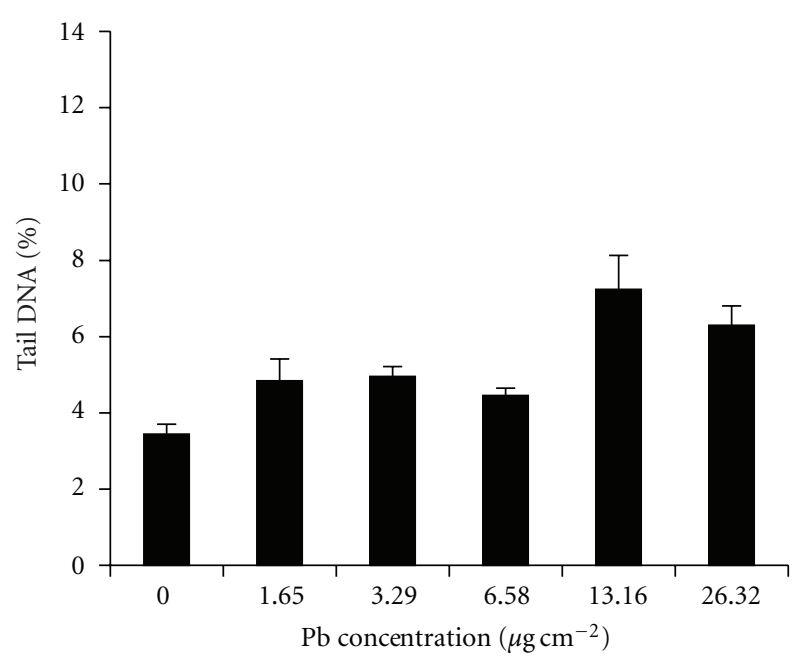

(b)

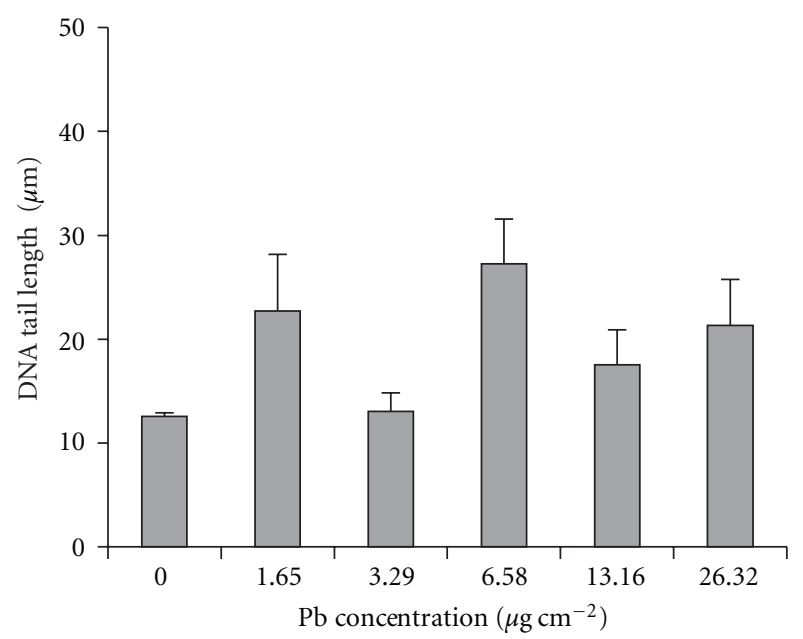

(d)

Figure 3: Tail DNA\% (a and b) and DNA tail length ( $\mathrm{c}$ and d) (mean \pm SE) of Pheretima peguana coelomocytes exposed to Cd (a and c) and $\mathrm{Pb}(\mathrm{b}$ and $\mathrm{d})$, respectively, in filter paper for 48 -h. ${ }^{*}$ Significantly different from the control $(P<.05)$.

greater at $0.75 \mu \mathrm{g} \mathrm{cm}^{-2}$ compared with the controls, confirming that $\mathrm{Cd}$ can induce DNA damage in earthworm coelomocytes at $50 \%$ of the 48 -h $\mathrm{LC}_{10}$, a sublethal concentration. Even though $\mathrm{Pb}$ at the highest concentrations of $26.32 \mu \mathrm{g} \mathrm{cm}^{-2}$ at near- $\mathrm{LC}_{10}$ concentration did not show any significant damage to DNA in the comet assay-confirming that $\mathrm{Pb}$, unlike $\mathrm{Cd}$, is not genotoxic even at $\mathrm{LC}_{10}$ concentration in a 48-h study. In support of these results, most authors report that Cd induces DNA strand breaks, sister chromatid exchanges, and chromosome aberrations in plant, mammalian and human cells [24-26] at relatively low exposure and well below the $48-\mathrm{h} \mathrm{LC} 10$ concentration.

Several metals_chromium, nickel, cobalt, and arsenicin addition to Cd have been shown to be carcinogenic to humans and experimental animals [27]. There are several possible mechanisms by which $\mathrm{Cd}$ induces DNA strand breaks, including inhibition of repair enzymes [4]. One reason for this inhibition could be the competition of $\mathrm{Cd}$ with zinc ions, which are essential for DNA polymerase activity. Besides, Cd might interfere with calcium-regulated processes that are involved in the regulation of DNA replication and repair. Snyder [28] and Ochi and Ohsawa [29] reported the involvement of reactive oxygen species in the generation of DNA single-strand breaks and that Cdmediated chromosomal aberrations occur when intracellular glutathione decrease.

In this study, the DNA damage in $P$. peguana caused by $\mathrm{Cd}$ at $0.75 \mu \mathrm{g} \mathrm{cm}^{-2}$ concentration is lower than that reported by Fourie et al. [15] who concluded that a much higher $\mathrm{Cd}$ concentration of $20 \mathrm{mg} \mathrm{L}^{-1}$ (sublethal dose) is required to induce DNA damage in Aporrectodea caliginosa, Dendrodrilus rubidus, and Eisenia fetida in an artificial soil-water medium. Toxicity to a lower Cd concentration as observed in this study is a reflection of the sensitivity of $P$. peguana coelomocytes to $\mathrm{Cd}$, but it is more likely because the earthworms in filterpaper tests are starved unlike those in a soil-water medium. It is also possible that a more heterogeneous coelomocyte population may be present in other earthworm species and therefore these are relatively more resistant than $P$. peguana to DNA damage. 
In conclusion, $\mathrm{LC}_{10}$ and $\mathrm{LC}_{50}$ values of $\mathrm{Cd}$ for $P$. peguana earthworms were 15 -fold and 7 -fold lower, respectively, than for $\mathrm{Pb}$, indicating that $\mathrm{Cd}$ was more toxic than $\mathrm{Pb}$. Cadmium was genotoxic and affected cytokinesis of $P$. peguana coelomocytes at $45 \%$ of the $48-\mathrm{h} \mathrm{LC}_{10}$ concentration. Lead at $\mathrm{LC}_{10}$ concentration did not affect DNA, but at $12.5 \%$ $\left(3.29 \mu \mathrm{g} \mathrm{cm}^{-2}\right)$ of the $\mathrm{LC}_{10}$ concentration, it affected cytokinesis.

\section{Acknowledgment}

This project was funded by the Faculty of Science, Silpakorn University, Nakorn Pathom, Thailand.

\section{References}

[1] H. Kula and O. Larink, "Tests on the earthworms Eisenia fetida and Aporrectodea caliginosa," in Handbook of Soil Invertebrate Toxicity Tests, H. Lokke and C. A. M. van Gestel, Eds., pp. 95112, John Wiley \& Sons, Chichester, UK, 1998.

[2] IARC (International Agency for Research on Cancer), "Inorganic and organic lead compounds," in IARC Monographs on the Evaluation of Carcinogenic Risks to Humans, vol. 87, pp. 1471, IARC, Lyon, France, 2006.

[3] IARC (International Agency for Research on Cancer), "Beryllium, cadmium, mercury, and exposures in the glass manufacturing industry," in IARC Monographs on the Evaluation of Carcinogenic Risks to Humans, vol. 58, pp. 119-237, IARC, Lyon, France, 1993.

[4] M. Waisberg, P. Joseph, B. Hale, and D. Beyersmann, "Molecular and cellular mechanisms of cadmium carcinogenesis," Toxicology, vol. 192, no. 2-3, pp. 95-117, 2003.

[5] L. R. Shugart, "DNA damage as a biomarker of exposure," Ecotoxicology, vol. 9, no. 5, pp. 329-340, 2000.

[6] B. Kurelec, "The genotoxic disease syndrome," Marine Environmental Research, vol. 35, no. 4, pp. 341-348, 1993.

[7] N. Fugère, P. Brousseau, K. Krzystyniak, D. Coderre, and M. Fournier, "Heavy metal-specific inhibition of phagocytosis and different in vitro sensitivity of heterogeneous coelomocytes from Lumbricus terrestris (Oligochaeta)," Toxicology, vol. 109, no. 2-3, pp. 157-166, 1996.

[8] N. P. Singh, M. T. McCoy, R. R. Tice, and E. L. Schneider, "A simple technique for quantitation of low levels of DNA damage in individual cells," Experimental Cell Research, vol. 175, no. 1, pp. 184-191, 1988.

[9] S. Cotelle and J. F. Férard, "Comet assay in genetic ecotoxicology: a review," Environmental and Molecular Mutagenesis, vol. 34, no. 4, pp. 246-255, 1999.

[10] S. A. Reinecke and A. J. Reinecke, "The comet assay as biomarker of heavy metal genotoxicity in earthworms," Archives of Environmental Contamination and Toxicology, vol. 46, no. 2, pp. 208-215, 2004.

[11] S. Sanchez-Galan, A. R. Linde, F. Ayllon, and E. GarciaVazquez, "Induction of micronuclei in eel (Anguilla anguilla L.) by heavy metals," Ecotoxicology and Environmental Safety, vol. 49, no. 2, pp. 139-143, 2001.

[12] T. Cavas, N. N. Garanko, and V. V. Arkhipchuk, "Induction of micronuclei and binuclei in blood, gill and liver cells of fishes subchronically exposed to cadmium chloride and copper sulphate," Food and Chemical Toxicology, vol. 43, no. 4, pp. 569$574,2005$.
[13] G. S. Eyambe, A. J. Goven, L. C. Fitzpatrick, B. J. Venables, and E. L. Cooper, "A non-invasive technique for sequential collection of earthworm (Lumbricus terrestris) leukocytes during subchronic immunotoxicity studies," Laboratory Animals, vol. 25, no. 1, pp. 61-67, 1991.

[14] P. Brousseau, N. Fugère, J. Bernier et al., "Evaluation of earthworm exposure to contaminated soil by cytometric assay of coelomocytes phagocytosis in Lumbricus terrestris (Oligochaeta)," Soil Biology and Biochemistry, vol. 29, no. 3-4, pp. 681-684, 1997.

[15] F. Fourie, S. A. Reinecke, and A. J. Reinecke, "The determination of earthworm species sensitivity differences to cadmium genotoxicity using the comet assay," Ecotoxicology and Environmental Safety, vol. 67, no. 3, pp. 361-368, 2007.

[16] J. Homa, E. Olchawa, S. R. Stürzenbaum, A. John Morgan, and B. Plytycz, "Early-phase immunodetection of metallothionein and heat shock proteins in extruded earthworm coelomocytes after dermal exposure to metal ions," Environmental Pollution, vol. 135, no. 2, pp. 275-280, 2005.

[17] J. Nahmani, M. E. Hodson, and S. Black, "A review of studies performed to assess metal uptake by earthworms," Environmental Pollution, vol. 145, no. 2, pp. 402-424, 2007.

[18] W. C. Ma, "The influence of soil properties and worm related factors on the concentration of heavy metals in earthworms," Pedobiologia, vol. 24, pp. 109-119, 1982.

[19] L. Z. Li, D. M. Zhou, P. Wang, and X. S. Luo, "Subcellular distribution of $\mathrm{Cd}$ and $\mathrm{Pb}$ in earthworm Eisenia fetida as affected by $\mathrm{Ca}^{2+}$ ions and $\mathrm{Cd}-\mathrm{Pb}$ interaction," Ecotoxicology and Environmental Safety, vol. 71, no. 3, pp. 632-637, 2008.

[20] J. M. Conder and R. P. Lanno, "Weak-electrolyte extractions and ion-exchange membranes as surrogate measures of cadmium, lead and zinc bioavailability to Eisenia fetida in artificial soils," Chemosphere, vol. 41, pp. 1659-1668, 2002.

[21] J. A. Heddle, M. C. Cimino, M. Hayashi et al., "Micronuclei as an index of cytogenetic damage: past, present, and future," Environmental and Molecular Mutagenesis, vol. 18, no. 4, pp. 277-291, 1991.

[22] V. Kašuba and R. Rozgaj, "Micronucleus distribution in human peripheral blood lymphocytes treated in vitro with cadmium chloride in $\mathrm{G}_{0}$ and $\mathrm{S}$ phase of the cell cycle," Chemosphere, vol. 49, no. 1, pp. 91-95, 2002.

[23] A. Çelik, "A study on the investigation of cadmium chloride genotoxicity in rat bone marrow using micronucleus test and chromosome aberration analysis," Toxicology and Industrial Health, vol. 21, no. 10, pp. 243-248, 2005.

[24] E. Gebhart and T. G. Rossman, "Mutagenicity, carcinogenicity, teratogenicity," in Metals and Their Compounds in the Environment, E. Merian, Ed., pp. 617-640, Wiley-VCH, Weinheim, Germany, 1991.

[25] A. Forni, "Comparison of chromosome aberrations and micronuclei in testing genotoxicity in humans," Toxicology Letters, vol. 72, no. 1-3, pp. 185-190, 1994.

[26] A. Hartwig, "Role of DNA repair inhibition in lead- and cadmium-induced genotoxicity: a review," Environmental Health Perspectives, vol. 102, supplement 3, pp. 45-50, 1994.

[27] A. Hartwig, "Carcinogenicity of metal compounds: possible role of DNA repair inhibition," Toxicology Letters, vol. 102-103, pp. 235-239, 1998. 
[28] R. D. Snyder, "Role of active oxygen species in metal-induced DNA strand breakage in human diploid fibroblasts," Mutation Research, vol. 21, pp. 359-365, 1988.

[29] T. Ochi and M. Ohsawa, "Participation of active oxygen species in the induction of chromosomal aberrations by cadmium chloride in cultured Chinese hamster cells," Mutation Research, vol. 143, no. 3, pp. 137-142, 1985. 

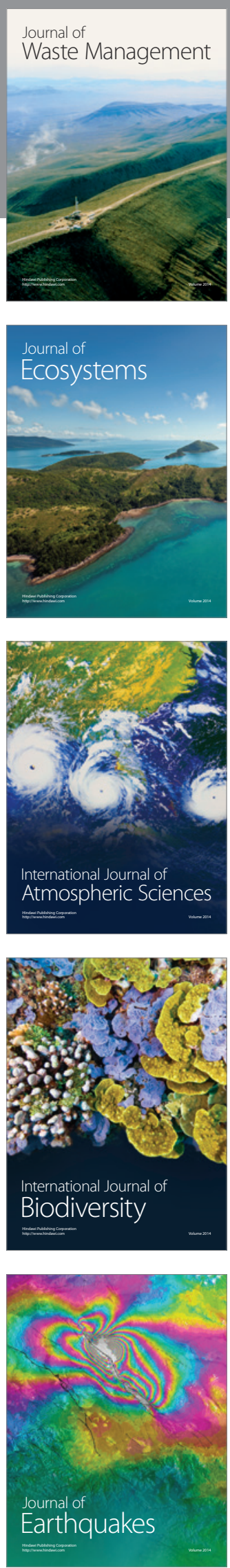
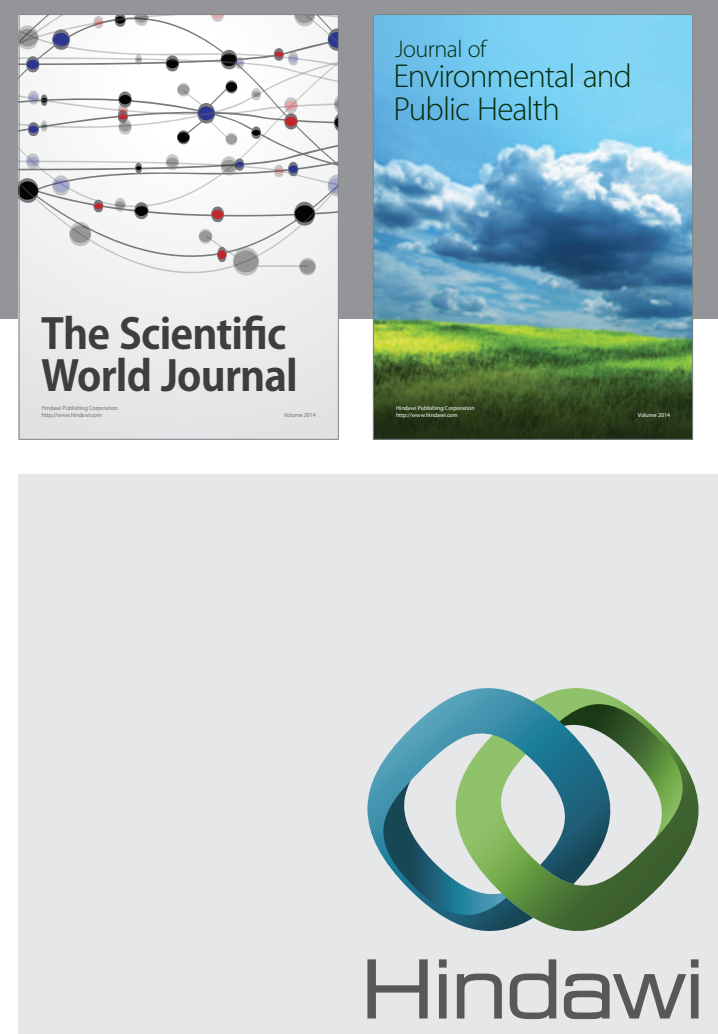

Submit your manuscripts at

http://www.hindawi.com
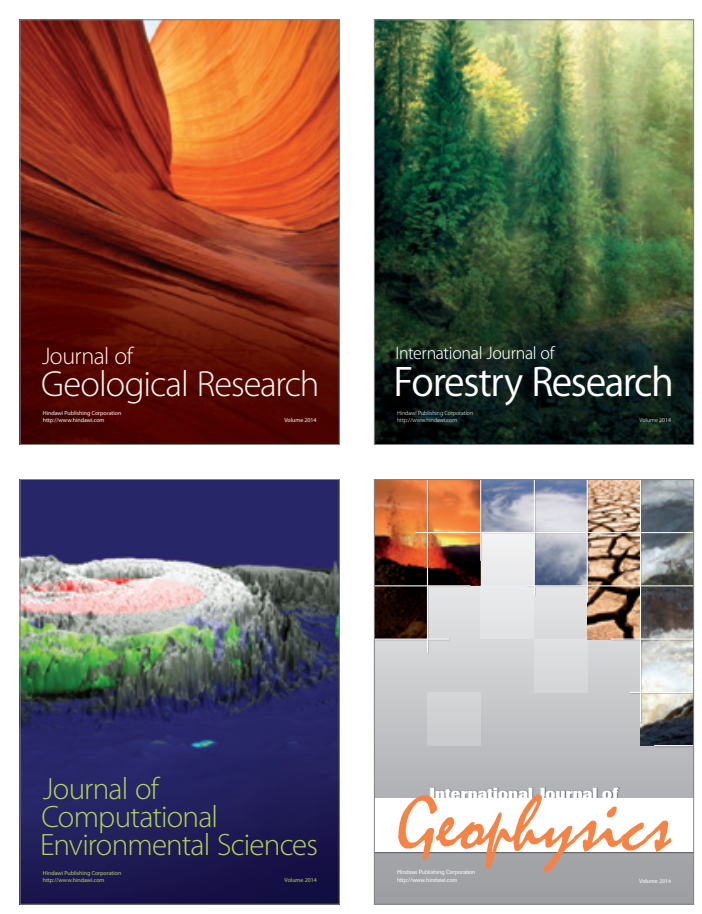
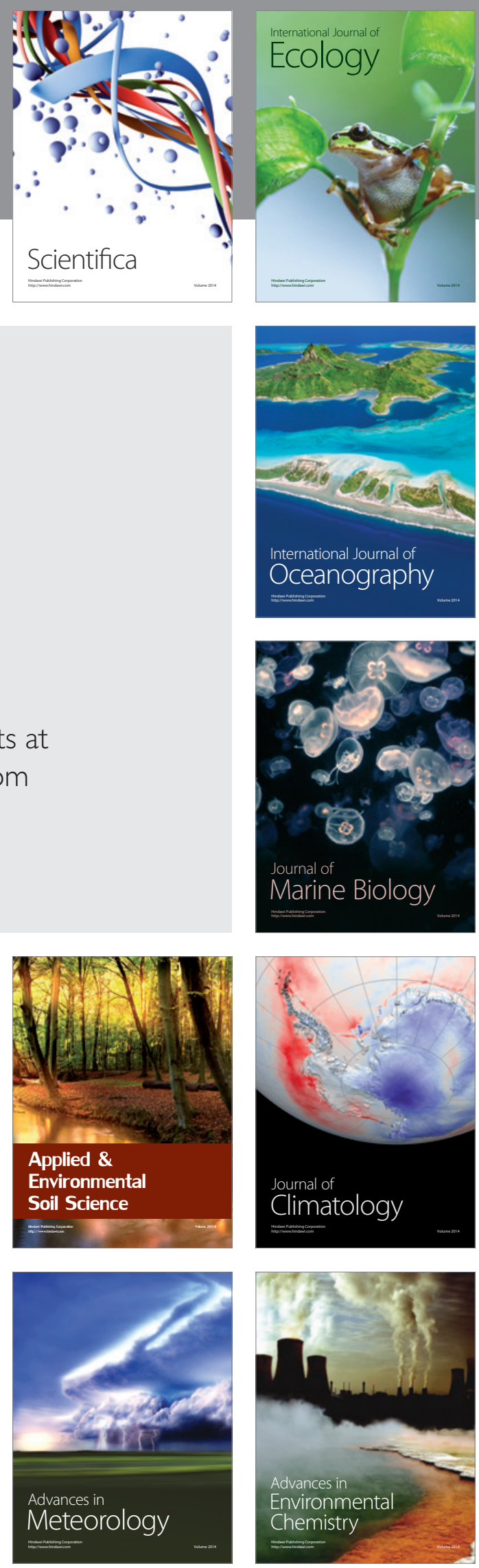